\title{
REAL ESTATE MARKET RATING - NEED OR NECESSITY?
}

\author{
Małgorzata Renigier-Biłozor, PhD \\ Faculty of Geodesy and Land Management \\ University of Warmia and Mazury in Olsztyn \\ e-mail:malgorzata.renigier@uwm.edu.pl
}

\author{
Radosław Wiśniewski, Assoc. prof., PhD \\ Faculty of Geodesy and Land Management \\ University of Warmia and Mazury in Olsztyn \\ e-mail:danrad@uwm.edu.pl
}

\begin{abstract}
Rating systems developed in Poland and other countries are generally used to evaluate the performance of businesses, organizations, institutions and even entire economies. Comprehensive solutions for assessing real estate markets and individual properties have never been proposed (several systems for evaluating mostly commercial real estate have been developed). This deficiency could be attributed to an absence of databases describing the real estate market and market changes as well as a shortage of coherent methods for analyzing real estate markets. In most cases, however, market phenomena may be difficult to classify because they involve behavioral, social and stochastic elements.

This article analyzes the existing systems for rating and ranking markets in different Polish regions and cities. They were compared with information about the classification of real estate markets on the example of selected property markets in Poland. Selected categories were evaluated to determine whether rating methods for real estate markets, including housing markets, should be developed for different Polish cities and regions. The growth potential of local real estate markets was also analyzed.
\end{abstract}

Keywords: market analysis, residential market, rating of residential market.

JEL Classification: R21, R31, R34.

Citation: Renigier-Biłozor M., Wiśniewski R., (2013), "Real estate market rating - need or necessity?", Real Estate Management and Valuation, vol. 21, no. 4 pp. 54-64.

DOI: $10.2478 /$ remav-2013-0037.

\section{Introduction}

Rating reports and publications have enjoyed widespread popularity around the world for some time. They are developed for various areas of life, and are becoming increasingly popular in Poland. A rating is a tool for evaluating the performance of an entity, and is an important part of market strategy. Rating is not synonymous to ranking, but the two words are often used interchangeably. In a ranking, the analyzed factors are arranged in groups, and are sorted within those groups without being placed in a specific order. A rating provides market participants with additional, sorted information about the reliability and performance of that market, the quality of market processes and the consequences of decisions made by market participants. Rating agencies evaluate the reliability of businesses, including their credit rating, as well as assessing the relevant investment risk. Agencies deploy standard rating procedures based on self-designed evaluation criteria.

The above considerations justify the question of whether ratings for different real estate markets are a need or a necessity. Regardless of the answer, market participants will always have a need for 
data that is classified, grouped and ordered. Ratings, which are an elaborate form of rankings, are, therefore, highly useful, if not indispensable. We need ratings to systematize complex and often specialized information about the real estate market. This knowledge is essential for all market participants who want to make well-informed decisions. Ratings should be developed to assist decision-makers and systematize our knowledge about the real estate market.

Ratings also play an important role in identifying market participants' demand for information about the condition of the real estate market. Market performance is determined by various factors, including economic growth, consumer demand, traditions and trends in a given region and the degree of state support for the construction sector. BARRAS (2004) identified four main phases of the real estate market: economic upturn, economic boom, economic downturn and recession. Every phase brings with it a specific response from the market (Fig. 1).

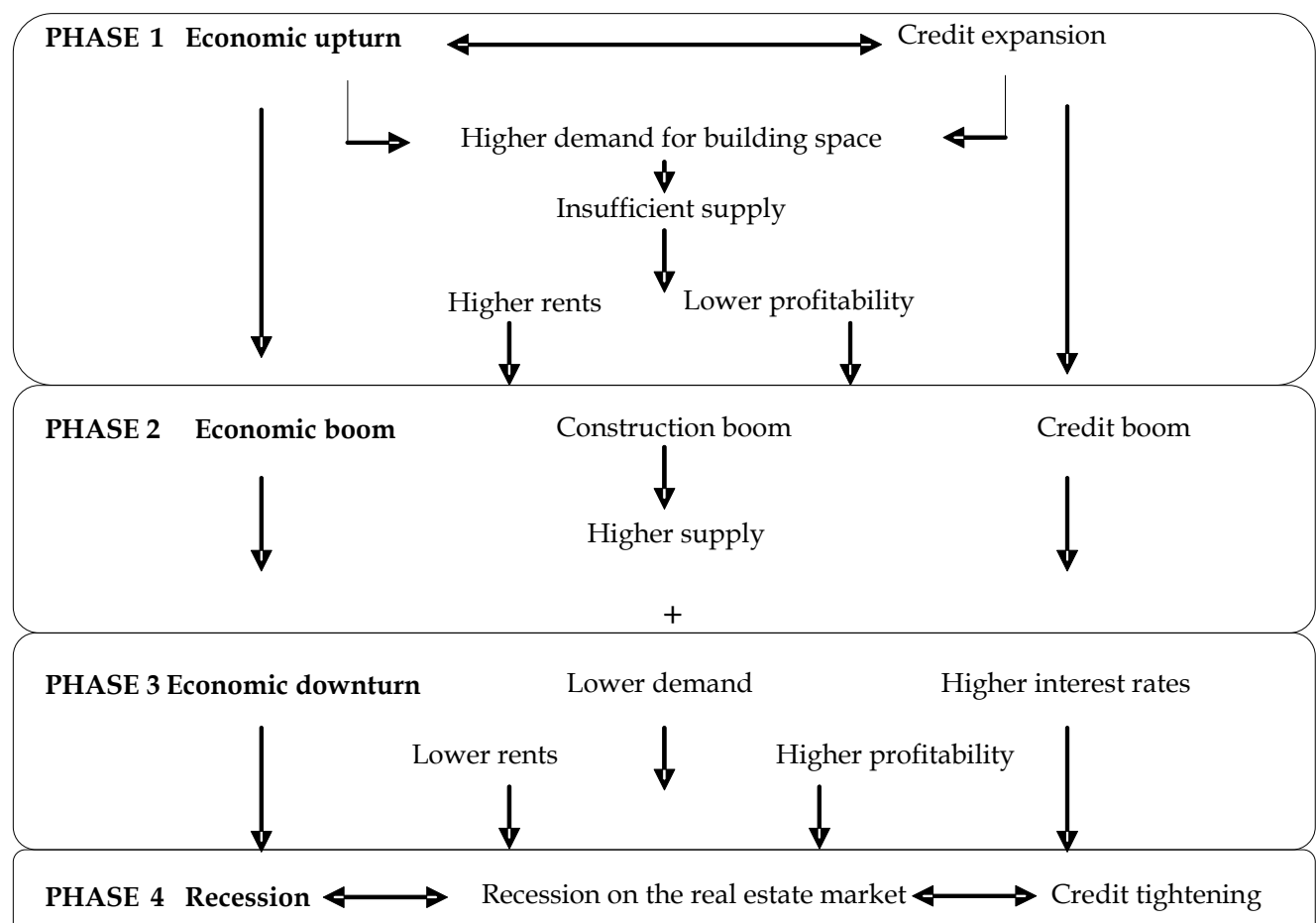

Fig. 1. Real estate market cycle. Source: BARRAS (1994).

In most cases, the initial stages of market expansion bring a steady growth of organizational efficiency and profitability. In a rapidly developing real estate market, market participants simply "push forward". When economic prosperity is achieved, market participants do not require additional information, including rating data. Growing profits compensate for the deficiency of market information. Market participants begin to search for such information, including rating data, in recession and depression phases of the cycle. The "need" for rating reports is, therefore, determined by the phase of the market cycle. It remains to be determined whether rating data is "indispensable" for market growth.

The transformation of the Polish real estate market began in 1990, and it brought significant legislative, political and social changes. According to estimates, $90 \%$ of the existing legislative solutions on the Polish market are characteristic of a developed market. This implies that the Polish property market has entered a path towards stable growth which is similar to the course adopted by countries with more highly developed market structures.

Rating data may be "indispensable" as a source of vital information for market participants in periods of economic downturn and recession. This scenario is currently observed on financial markets. Rating agencies develop reports which classify and grade institutions and entire economies. On the contemporary market, ratings play an important role in evaluating financial performance and credit worthiness. According to DZIAWGO (2010), credit ratings are a useful tool in controlling and minimizing investment risk on the financial market, nevertheless, they have a number of 
shortcomings which do not arise from the very concept of a credit rating, but rather the irresponsible behavior of market participants.

Real estate markets should be rated because they are an integral part of the national economy, and play a similar role in most economic systems around the globe. Rating systems should not be obligatory, but they should evolve naturally with real estate markets.

\section{Ratings and rankings of Polish cities}

After the political transformations of 1989, Polish rating tools were developed in line with the trends observed in Europe. The above does not apply to real estate market ratings which are generally not developed in Poland or other countries. Polish rating agencies develop periodic rankings and ratings which directly or indirectly address the real estate market. The selected rankings and ratings of Polish regional capital cities are overviewed in successive parts of this article.

\subsection{Ranking of Polish cities}

Polish cities are periodically ranked by the Rzeczpospolita daily and the Przekrój magazine. The evaluated categories include population, unemployment, incomes, availability of nursery schools and kindergartens, utilization of EU funds, free Wi-Fi internet access, and the availability of swimming pools, cycle paths, cinemas, theaters and municipal parks. Cities are ranked based on data supplied by the Central Statistical Office and acquired by the authors. The results are presented in Table 1 and Figure 2.

Table 1

Ranking of Polish cities

\begin{tabular}{|c|c|c|c|c|c|c|c|c|}
\hline \multicolumn{2}{|c|}{ Regional capital cities } & Gdańsk & Olsztyn & Szczecin & Bydgoszcz & Białystok & Poznań & Warsaw \\
\hline & 1 & 2 & 3 & 4 & 5 & 6 & 7 & 8 \\
\hline & ty of life & 382 & 344 & 343 & 376 & 364 & 382 & 353 \\
\hline Łódź & Wroclaw & Lublin & cow & Rzeszów & Zielona Góra & Kielce & Katowice & Opole \\
\hline 9 & 10 & 11 & 22 & 13 & 14 & 15 & 16 & 17 \\
\hline 333 & 360 & 297 & 76 & 344 & 303 & 306 & 394 & 348 \\
\hline
\end{tabular}

Source: own study based on Przekrój magazine (2011).

\subsection{FitchRatings Polska: long-term credit rating of Polish cities}

Table 2

Long-term credit rating of Polish cities

\begin{tabular}{|c|c|c|c|c|c|c|c|c|}
\hline \multicolumn{2}{|c|}{ Regional capital cities } & Gdańsk & Olsztyn & Szczecin & Bydgoszcz & Białystok & Poznań & Warsaw \\
\hline & 1 & 2 & 3 & 4 & 5 & 6 & 7 & 8 \\
\hline \multicolumn{2}{|c|}{ FitchRatings } & AA - & $\mathrm{BBB}+$ & BBB+ & A & A & $\mathrm{AA}+$ & AAA \\
\hline Łódź & Wrocław & Lublin & Cracow & Rzeszów & Zielona Góra & Kielce & Katowice & Opole \\
\hline 9 & 10 & 11 & 12 & 13 & 14 & 15 & 16 & 17 \\
\hline AA- & $A+$ & $\mathrm{BBB}+$ & AA & $\mathrm{A}+$ & A- & A- & $\mathrm{AA}+$ & BBB+ \\
\hline
\end{tabular}

Source: Own study based on FITCHRATINGS POLSKA (2012).

FitchRatings Polska analyzed the credit rating of Polish cities against the "lowest" credit risk rating in the country as the benchmark. In general, the "lowest" credit risk is associated with debt obligations issued by the State Treasury. For this reason, national ratings performed in Poland cannot be compared with national ratings in other countries or with international ratings (FITCHRATINGS POLSKA 2012). Rating scores are given in Table 2 and Figure 3. 


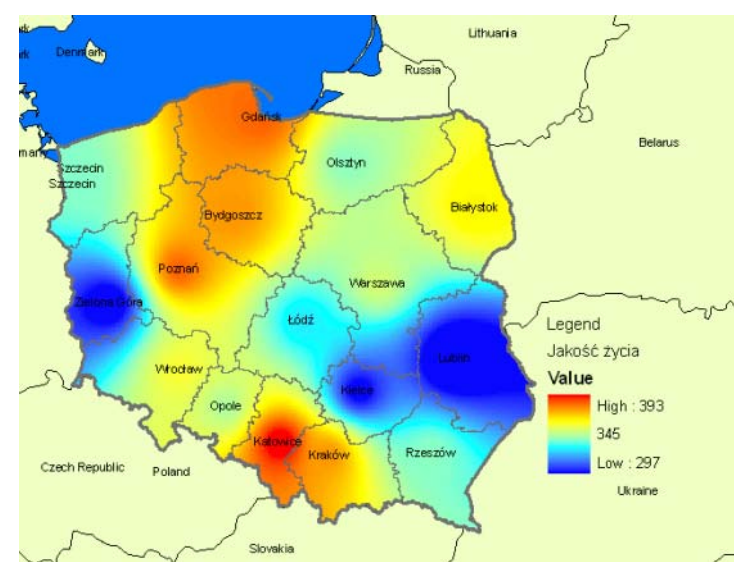

Fig. 2. Ranking of Polish cities- quality of life. Source Own study based on Table 1.

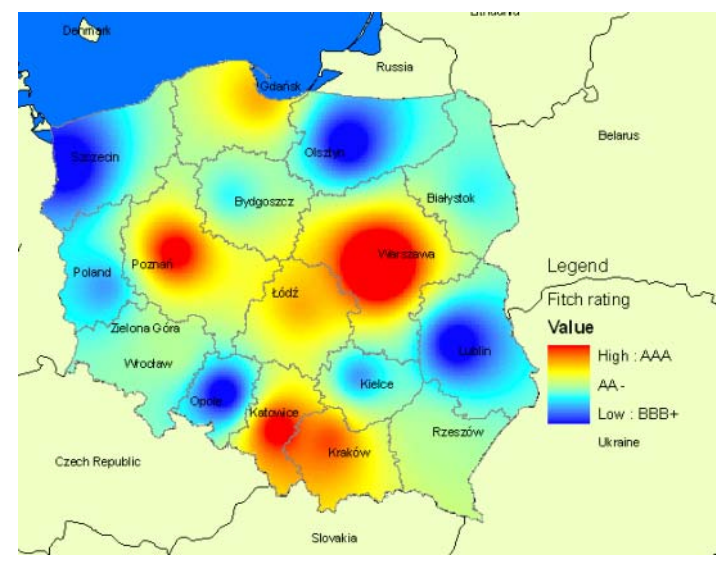

Fig. 3. Long-term credit rating of Polish cities by Fitch Polska. Source. Own study based on Table2.

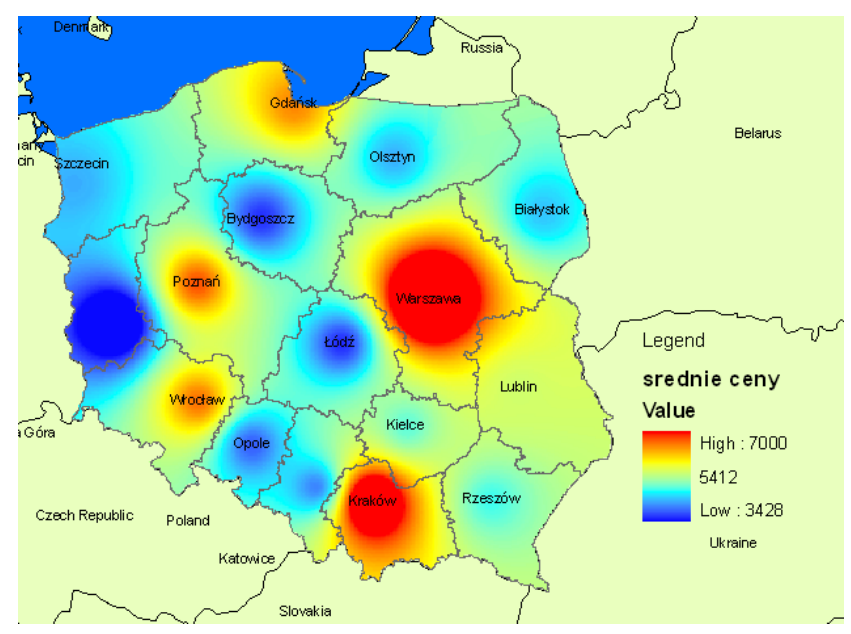

Fig. 4. Ranking of Polish cities - housing prices [average transaction price in $3 \mathrm{Q}$ 2012]. Source. Own study based on Table

3.

Table 3

Ranking of Polish cities - housing prices [PLN/ $\left.\mathrm{m}^{2}\right]$

\begin{tabular}{cccccccc}
\hline Regional capital cities & Gdańsk & Olsztyn & Szczecin & Bydgoszcz & Białystok & Poznań & Warsaw \\
\hline 1 & 2 & 3 & 4 & 5 & 6 & 7 & 8 \\
\hline $\begin{array}{c}\text { Average transaction price } \\
\text { in 3Q 2012 }\end{array}$ & 5412 & 4298 & 4285 & 3953 & 4342 & 5553 & 7002 \\
\hline
\end{tabular}

\begin{tabular}{ccccccccc}
\hline Łódź & Wrocław & Lublin & Cracow & Rzeszów & Zielona Góra & Kielce & Katowice & Opole \\
\hline 9 & 10 & 11 & 12 & 13 & 14 & 15 & 16 & 17 \\
\hline 3945 & 5472 & 4875 & 6403 & 4521 & 3428 & 4574 & 4187 & 4084 \\
\hline
\end{tabular}

Source: own study based on data supplied by the National Bank of Poland (www.nbp.pl).

\subsection{Ranking of Polish cities - housing prices}

The authors have developed a ranking of Polish cities based on average transaction prices of new and second-hand property based on the data supplied by the National Bank of Poland for the last quarter of 2012. Rating scores are presented in Table 3 and Figure 4.

\subsection{Evaluation of Polish cities based on the presented criteria}

The presented rankings and ratings are only a rough guide, and they cannot be used to perform 
detailed analyses of local real estate markets in Poland. They do not directly address the real estate market but, as indirect indicators of market condition, can be used for comparative purposes.

In the discussed rankings, Polish cities with the highest the quality of life are Gdańsk, Poznan, Cracow and Katowice. The highest credit scores were also reported in the above cities as well as in Warsaw and Łódź. Warsaw, Gdańsk, Poznań, Cracow and Wrocław are characterized by the highest housing prices. All of the ratings are topped by the largest cities. The discussed rankings are not identical, and all of them contain similarities as well as differences.

Significant similarities are found between the long-term credit rating of Polish cities and the rating based on the average transaction prices quoted on the market of new and second-hand property. Cities with a stable credit rating are characterized by high property prices, and the opposite also applies: cities with a poor credit rating have lower housing prices. Housing prices are correlated with credit worthiness. The presented ratings also divide Poland into two zones: A (large and/or more populated and better developed cities) and B (smaller and/or less populated and less developed cities).

The presented ratings do not support a comprehensive evaluation of the real estate market. They cover only selected elements of the property market, such as housing prices. The prices of property are not the most accurate indicators of the situation on the real estate market. They are a mere reflection of the usable value of property at a given point in space and time. Moreover, property prices do not present the situation on the real estate market in a comprehensive manner. A professional rating of the real estate market should be developed to address those discrepancies and shortcomings.

\section{Methodology for rating Polish real estate markets}

The development of a methodology for rating entire real estate markets is a very difficult process; nevertheless, it would significantly contribute to optimal decision-making on the property market. The proposed rating procedure has to account for the specific character of the analyzed area. A general diagram of a rating procedure proposed by RENIGIER-BIŁOZOR and WIŚNIEWSKI (2012b) for the real estate market is presented in Figure 5.

The procedure of developing real estate market ratings has been divided into several modules to simplify the complex process of evaluating property markets based on ratings. The selection of factors which are indicative of the growth potential of a local market poses the greatest problem. Based on module IVA (Fig. 5), the authors have proposed a set of diagnostic factors as a "rating toolkit" for the housing market.

Since the main aim of a rating is to provide quick, objective, reliable and updated information, a dataset has to be developed as a platform for quantitative and qualitative analyses. In view of the specific character of the real estate market, the availability of market information and the sudden and unpredictable changes that often occur on that market, the developed system for gathering market data should be flexible enough to enable frequent modifications.

The choice of data which will be later converted into sets of variables should account for different aspects of market activity. The authors have analyzed numerous reviews and analyses of real estate markets, in particular residential housing markets (IRWIN et al. (1993), JAFFE and SIRMANS (1989), BRYX and MATKOWSKI (2001), BALL and WOOD (1999), Case (2000)), RENIGIER-BIŁOZOR and WISNIEWSKI (2011a and 2012b), and they have compiled the existing knowledge to propose indicator sets for rating real estate markets.

\section{1. "Rating toolkit" for the housing market}

The proposed set of indicators ("rating toolkit") is determined by the availability of market data and comparability of data that characterizes different markets. It has been developed in view of factors that condition demand and supply on the real estate market. In the simulation, the reference unit will be the capital city of a Polish voivodeship.

Group Ia - political and economic (supply-side) indicators:

- indicator 1a - local government's spending on housing policy (in PLN '000 per person) (in the last four years: 2008-2011),

- indicator $2 \mathrm{a}$ - percent of land covered by zoning plans (percent of land covered by local zoning plans in 2011).

Group Ib - political and economic (demand-side) indicators:

- indicator 3b - local government's spending per 1 resident in recent years (2009-2011) 


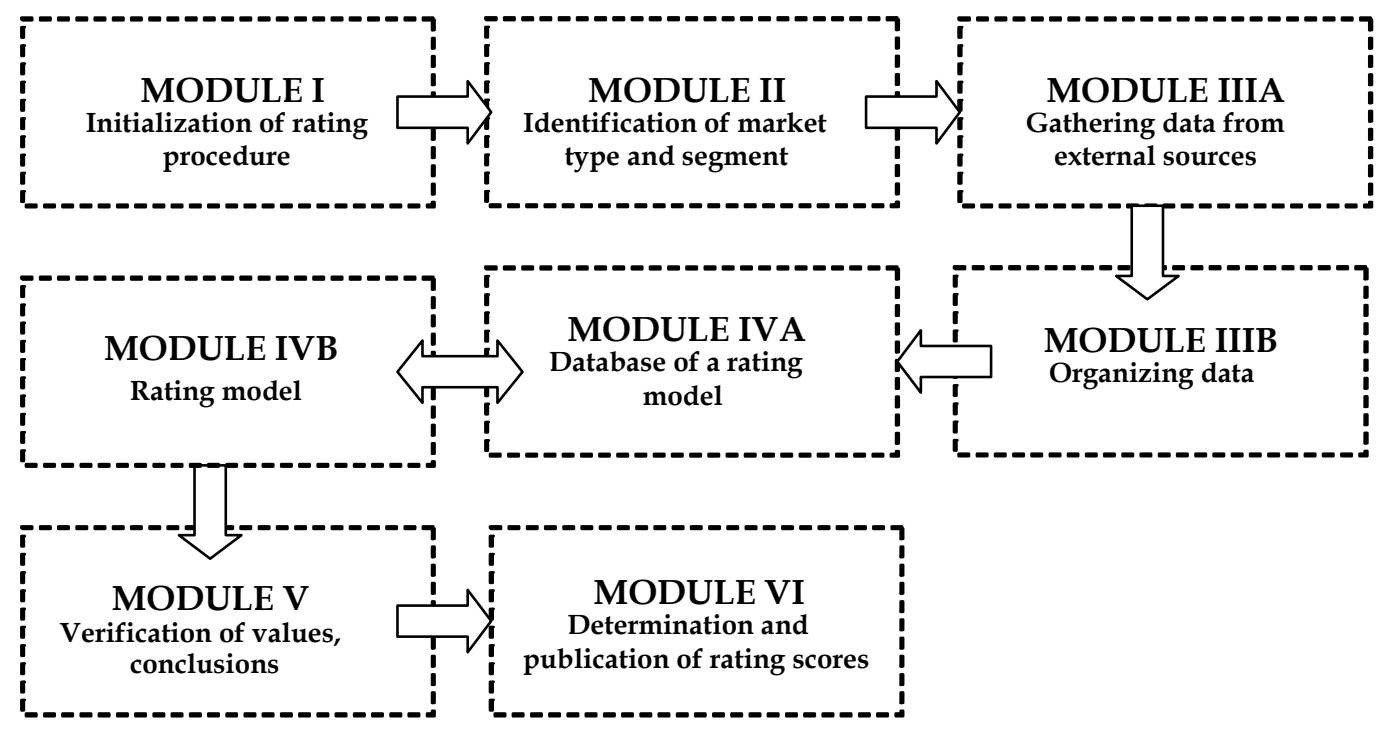

Fig. 5. Diagram of a rating procedure, Source. own study based on RENIGIERBIŁOZOR and WIŚNIEWSKI (2012b).

- indicator $4 \mathrm{~b}$ - local government's spending on promotion as a share of total expenditures (in the last four years: 2008-2011),

- indicator $5 b$ - difference between the national average salary and the average salary on the local market in a given year (2012),

- indicator 6b - unemployment rate (2011),

- indicator $7 \mathrm{~b}$ - number of new registered businesses (number of new businesses per 1,000 residents) (2009-2011).

Group IIa - market (supply-side) indicators:

- indicator 8a - total number of issued construction permits (2012),

- indicator 9a - number of issued construction permits - individual (2012),

- indicator 10a - number of property offers per 1,000 residents (November 2012),

- indicator 11a - ratio of replacement value per $1 \mathrm{~m}^{2}$ of property to the average price quoted on the local real estate market (2012),

- indicator $12 \mathrm{a}$ - number of property offers - average from the most popular websites (November 2012),

- indicator 13a - number of developers on the local market (2011),

- indicator 14a - affordability of rental housing (number of square meters that can be financed from an average local salary per month) (November 2011),

- indicator $15 \mathrm{a}$ - difference between the average prices of new and second-hand property (1Q 2012),

- $\quad$ indicator $16 a$ - number of new apartments per 1,000 residents (2011).

Group IIb - market (demand-side) indicators:

- indicator $17 \mathrm{~b}$ - average purchasing power in comparison with the national average - ratio of the average national salary to the average price of property on the local market in a given year (2012),

- indicator $18 b$ - number of property transactions per 1,000 residents (2011),

- indicator 19b - purchasing power on the local housing market (average salary on the local market / average price per $1 \mathrm{~m}^{2}$ of property on the local market) (2012),

- indicator 20b - changes in local property prices (2011 - 1Q 2012, average quarterly prices),

- indicator $21 \mathrm{~b}$ - ratio of replacement value of $1 \mathrm{~m}^{2}$ of property and the average transaction price on the local real estate market (2012),

- indicator 22b - average time on the market in months (2012), 
- indicator 23b - number of real estate agents on the local market (2011),

- indicator $24 \mathrm{~b}$ - availability of mortgages in terms of $\mathrm{m}^{2}$ (average property price / average credit rating of a family or individual) (2011),

- indicator 25b - value of property transaction per 1 resident on the local market (2011).

Group IIIa - social (supply-side) indicators:

- indicator 26a - number of deaths (2011, older than 50),

- indicator 27a - existing residential area per 1 resident (2011),

- indicator 28a - number of residents per 1 existing apartment (2011).

Group IIIb - social (demand-side) indicators:

- indicator $29 \mathrm{~b}$ - population density per $\mathrm{m}^{2}(2011)$,

- indicator 30b - number of marriages (2011),

- indicator 31b - number of divorces (2011),

- indicator 32b - net migration rate (2011),

- indicator 33b - population growth (2011),

- indicator 34b - age structure of potential clients (2011 - 25-45 population group vs. total population in a given area),

- indicator 35b - quality of life, measured in terms of the fulfillment of local residents' basic needs (2010-2011):

- nurseries, kindergartens,

- schools, universities,

- quality of transport infrastructure, including road quality, traffic parameters (congestion), internal and external public transport,

- crime rate,

- health care,

- cultural facilities, e.g., cinemas, theaters, museums,

- recreational facilities, e.g., swimming pools, spas,

- recreational areas, e.g., parks, forests, water reservoirs,

- air pollution.

The above indicators were gathered and processed numerically (Annex 1) based on data supplied by:

- The National Bank of Poland, report on the residential property market in 2011,

- Central Statistical Office, local data bank, 2008-2012,

- The Polish Bank Association, AMRON - SARFIN reports,

- Local government rankings by the Rzeczpospolita daily and the Przekrój magazine, 2010.

The proposed rating procedure was used to develop the analytical model. The analytical model was based on the rough set theory because it was to be used to analyze data that is qualitatively and quantitatively ambiguous, imprecise and varied. Zdzisław Pawlak (1982, 1991, 1997), a Polish professor of computer science, developed the rough set theory to analyze imprecise and vague data which is commonly found on the real estate market and accompanies decision making (fuzzy decision making) on that market. The theory is used in many sciences, and it is often applied as the main support tool in decision-making systems (BELLO and VERDEGAY (2012), CHI et al. (2011), CHUNG and TSENG (2012), POLKOWSKI and SEMENIUK-POLKOWSKA (2010), ZAVADSKAS and TURSKIS (2011), ZHANG 2012, RENIGIER-BIEOZOR (2011), RENIGIER-BIEOZOR and WIŚNIEWSKI (2011a and b, 2012a and b).

\section{Similarities and growth potential of selected real estate markets}

The analytical model, developed based on the rough set theory (RENIGIER-BItOZOR 2011), was used to determine similarities between selected real estate markets. Indicators listed in the "rating toolkit" were applied (section 3.1). Market data was analyzed to form groups of similar markets. The results of the analyses are presented in Table 4.

\section{Conclusions}

In the past decade, the growing complexity of management (enforced or not enforced management of the real estate market by authorized entities), as well as technical (development of new tools for data acquisition, processing and release) and procedural (legal intervention in unregulated market areas) structures have changed real estate markets. Those systems have become "active" and "equal" management instruments which are no longer the recipients, but rather the creators of investments. Increasingly complex markets with decreasingly legible structure and decision-making processes need 
tools with high information content. Those tools have to be simple and easy to access because they are targeted at market participants with different levels of knowledge about the market.

Table 4

Results produced by the analytical model

\begin{tabular}{|c|c|c|c|c|c|}
\hline $\begin{array}{c}\text { Group Ia - } \\
\text { political and } \\
\text { economic } \\
\text { (supply - side) } \\
\text { indicators - } \\
75 \% \text { similarity }\end{array}$ & $\begin{array}{l}\text { Group Ib - } \\
\text { political and } \\
\text { economic } \\
\text { (demand -side) } \\
\text { indicators - } \\
75 \% \text { similarity }\end{array}$ & $\begin{array}{l}\text { Group IIa - } \\
\text { market } \\
\text { (supply -side) } \\
\text { indicators - } \\
70 \% \text { similarity }\end{array}$ & $\begin{array}{l}\text { Group IIb - } \\
\text { market } \\
\text { (demand - } \\
\text { side) } \\
\text { indicators - } \\
70 \% \\
\text { similarity }\end{array}$ & $\begin{array}{c}\text { Group IIIa - } \\
\text { social } \\
\text { (supply -side) } \\
\text { indicators - } \\
75 \% \\
\text { similarity }\end{array}$ & $\begin{array}{c}\text { Group IIIb - } \\
\text { social } \\
\text { (demand - } \\
\text { side) } \\
\text { indicators - } \\
75 \% \\
\text { similarity }\end{array}$ \\
\hline Gdańsk & $\begin{array}{l}\text { Gdańsk, } \\
\text { Katowice }\end{array}$ & Gdańsk & Gdańsk & Gdańsk & $\begin{array}{c}\text { Gdańsk, } \\
\text { Szczecin, } \\
\text { Bydgoszcz, } \\
\text { Katowice }\end{array}$ \\
\hline $\begin{array}{c}\text { Olsztyn, } \\
\text { Szczecin, } \\
\text { Bydgoszcz, } \\
\text { Biatystok, } \\
\text { Poznań, } \\
\text { Warsaw, Lublin, } \\
\text { Cracow, Opole }\end{array}$ & $\begin{array}{c}\text { Olsztyn, } \\
\text { Szczecin, } \\
\text { Białystok, Łódź, } \\
\text { Poznań, Lublin, } \\
\text { Rzeszów, Kielce, } \\
\text { Opole }\end{array}$ & $\begin{array}{c}\text { Olsztyn, } \\
\text { Białystok, } \\
\text { Lublin, Zielona } \\
\text { Góra, Kielce, } \\
\text { Katowice, } \\
\text { Szczecin, Opole, } \\
\text { Rzeszów }\end{array}$ & Olsztyn & $\begin{array}{c}\text { Olsztyn, } \\
\text { Bydgoszcz, } \\
\text { Szczecin, } \\
\text { Lublin, } \\
\text { Rzeszów, } \\
\text { Zielona Góra, } \\
\text { Kielce, } \\
\text { Katowice }\end{array}$ & $\begin{array}{c}\text { Poznań, } \\
\text { Wroctaw, } \\
\text { Kraków, Łódź }\end{array}$ \\
\hline $\begin{array}{c}\text { Łódź, Rzeszów, } \\
\text { Kielce }\end{array}$ & $\begin{array}{l}\text { Bydgoszcz, } \\
\text { Zielona Góra }\end{array}$ & Bydgoszcz & $\begin{array}{l}\text { Szczecin, } \\
\text { Białystok, } \\
\text { Wrocław, } \\
\text { Lublin, } \\
\text { Rzeszów, } \\
\text { Kielce, Opole }\end{array}$ & Biatystok & $\begin{array}{c}\text { Klelce, } \\
\text { Olsztyn, } \\
\text { Rzeszów, } \\
\text { Zielona Góra, } \\
\text { Opole, } \\
\text { Białystok, } \\
\text { Lublin }\end{array}$ \\
\hline $\begin{array}{l}\text { Wrocław, } \\
\text { Zielona Góra }\end{array}$ & Warsaw & Poznań & Poznań & $\begin{array}{l}\text { Poznań, Łódź, } \\
\text { Wrocław, } \\
\text { Cracow }\end{array}$ & Warsaw \\
\hline \multirow[t]{5}{*}{ Katowice } & $\begin{array}{l}\text { Wroctaw, } \\
\text { Cracow }\end{array}$ & Łódź & Warsaw & Warsaw & \\
\hline & & Warsaw & $\begin{array}{l}\text { Bydgoszcz, } \\
\text { Łódź }\end{array}$ & Opole & \\
\hline & & $\begin{array}{l}\text { Wroctaw, } \\
\text { Cracow }\end{array}$ & Cracow & & \\
\hline & & & Zielona Góra & & \\
\hline & & & Katowice & & \\
\hline
\end{tabular}

Source own study.

The results presented in Table 4 reveal similarities and differences between selected real estate markets in Poland. As regards similarities, selected indicator groups were represented by a single city. The above applies to Gdańsk (the only city to represent four groups), Warsaw, Poznań and Łódź. Differences resulted from the specific character of local real estate markets. Small cities, such as Zielona Góra or Olsztyn, are almost never encountered as the sole representatives of indicator groups.

In a more in-depth analysis, the evaluated cities can be sorted within groups according to a given level of similarity. The following cities were characterized by similarities in the group of political and economic indicators: 1) Olsztyn, Szczecin, Białystok, Poznań, Lublin, Rzeszów, Kielce and Opole, 2) no similarities were observed between the remaining cities. In the group of market indicators, the following cities were found to be similar: 1) Szczecin, Białystok, Lublin, Rzeszów, Kielce and Opole, 2) the remaining cities showed no similarities based on the adopted criteria. Two groups of similar cities were identified in an analysis based on social indicators: 1) Bydgoszcz, Szczecin, Lublin, Rzeszów, Zielona Góra, Kielce and Katowice, 2) Poznań, Wrocław and Kraków, 3) no similarities were observed between the remaining cities. The most diverse cities are found in the group of market indicators, even when the probability level is lowered to $70 \%$. The above is not surprising in view of the specific character, complexity and heterogeneity of real estate markets.

The results of this study will support experts in making decisions and verifying data in successive stages of the rating process in module V (Fig. 5). In follow-up research, the results will be used to 
develop the first rating system for real estate markets in Poland.

\section{References}

BALL M., WoOD A. (1999), Housing investment: long run international trends and volatility, Housing Studies, 14 (2) (1999), pp. 185-209.

BARRAS R., (1994), Property and the Economic Cycle - Building Cycles Revisited, Journal of Property Research", nr 11, s. 183-197, za: GRANELLE J.J., Economie immobiliere pp. 499.

Bello R., Verdegay J. L., (2012), Rough sets in the Soft Computing Environment, Original Research Article Information Sciences, Volume 212, 1 December 2012, Pages 1-14.

BryX M., MATKOWSKI R. (2001), Inwestycje w nieruchomości, Poltext, Warszawa.

CASE K., (2000), Real Estate and the Macroeconomy, Brookings Papers of Economic Activity, 2 pp. 119145.

CHUNG W. , TSENG T., (2012), Discovering business intelligence from online product reviews: A rule-induction framework, Expert systems with applications, Volume: 39, issue: 15, pp: 11870-11879.

DZIAWGO D., (2010), Credit rating na międzynarodowym rynku finansowym, Polskie Wydawnictwo Ekonomiczne, Warszawa.

FITCHRATINGS POLSKA, (2012), Real Estate Advisory Service - bazy wiedzy, http:/ / www.fitchpolska.com.pl, (12.2012).

GUS, (2012), www.stat.gov.pl/bdl/app/strona.html?p_name=indeks, (12.2012).

IRwIN R., (1993), The McGraw-Hill Real Estate Handbook, McGraw-Hill, Inc. 1993.

JAFFE A., SIRMANS C., (1989), Fundamentals of real Estate Investment, Prentice Hall Inc. 1989.

NBP, (2012), http://nbp.pl/home.aspx?f=/publikacje/rynek_nieruchomosci/

index2.html, (12.2012).

PAWLAK Z., (1982), Rough sets, International Journal of Information and Computer Science 11: 341.

PAWLAK Z., (1991), Rough sets: Theoretical aspects of reasoning about data, Kluwer Academic Press, Dordrecht.

PAWLAK Z., (1997), Rough Sets and their Applications, Seminar Department of Computing - Macquarie University.

POLKOWSKI L., SEMENIUK-POLKOWSKA M., (2010), Granular Rough Mereological Logics with Applications to Dependencies in Information and Decision Systems, Journal: Transactions on Rough Sets, vol. 12.

PRZEKRÓJ, (2011), Ranking miast, Przekrój we współpracy z Rzeczpospolitą vol. 11, 2011.

RAPORT AMRON - SARFIN, (2012), http://cigi.pl/index.php?option= com_content\&view $=$ article\&id=271\&Itemid=102, (12.2012).

RENIGIER-BIŁOZOR M., (2011), Analysis of real estate markets with the use of the rough set theory, wyd. Journal of the Polish real estate scientific society, vol. 19, nr 3, 2011, Olsztyn pp. 107-118.

RENIGIER-BIŁOZOR M., WIŚNIEWSKI R., (2011a), The impact of macroeconomic factors on residential property prices indices in Europe, Referat wygłoszony i opublikowany na konferencji pt. APPRAISALS Evolving Proceedings in Global Change organizowanej przez The Centro Studi di Estimo e di Economia Territoriale - Ce.S.E.T. in November 14th and 15th 2011 in Rome (Italy).

RENIGIER-BIŁOZOR M., WIŚNIEWSKI R., (2011b), The efficiency of selected real estate markets in Poland, Acta Scientiarum Polonorum, Oeconomia 10 (1), 2011, pp.83-96.

RENIGIER-BIŁOZOR M., WiśNIEWSKI R., (2012a), The Effectiveness of Real Estate Market Participants, European Spatial Research and Policy, vol. 19, no 1, Publisher: Versita, Warsaw pp. 95-110.

RENIGIER-BIŁOZOR M., WIŚNIEWSKI R., (2012b), Rating rynków nieruchomości - analiza teoretyczna, Studia i Materiały Towarzystwa Naukowego Nieruchomości, vol. 20, nr 2, pp. 59-70.

ZAVADSKAS E. TURSKIS Z., (2011), Multiple criteria decision making (MCDM) methods in economics: an overview, Technological and economic development of economy, volume: 17, issue 2, pp: 397-427.

ZHANG Z., (2012), A rough set approach to intuitionistic fuzzy soft set based decision making, APPLIED Mathematical modeling, volume 36, issue 10, pp: 4605-4633. Wydawnictwo Naukowe, tom 1, Warszawa. 


\section{Annex 1}

Indicators from the "ranking toolkit" for the housing market*

\begin{tabular}{|c|c|c|c|c|c|c|c|c|c|c|c|c|}
\hline No. & City & $1 \mathrm{a}$ & $2 a$ & $3 b$ & $4 b$ & $5 b$ & $6 b$ & $7 b$ & $8 a$ & $9 a$ & $10 a$ & $11 \mathrm{a}$ \\
\hline 1 & Gdańsk & 419.00 & 64 & 12677 & 0.75 & 1034 & 5.9 & 38 & 3203 & 279 & 50.0 & 123.59 \\
\hline 2 & Olsztyn & 93.00 & 44 & 11888 & 0.47 & -222 & 7.8 & 35 & 911 & 72 & 28.0 & 102.86 \\
\hline 3 & Szczecin & 247.00 & 41 & 9696 & 0.52 & 96 & 10.5 & 42 & 2704 & 226 & 39.0 & 128.04 \\
\hline 4 & Bydgoszcz & 35.00 & 31 & 10101 & 1.07 & -401 & 8.2 & 31 & 1255 & 139 & 64.0 & 76.67 \\
\hline 5 & Białystok & 393.00 & 33 & 12389 & 0.48 & -576 & 12.7 & 34 & 1184 & 156 & 20.0 & 123.35 \\
\hline 6 & Poznań & 340.00 & 31 & 13112 & 0.65 & 472 & 3.8 & 45 & 4438 & 526 & 33.0 & 115.07 \\
\hline 7 & Warsaw & 379.00 & 29 & 18684 & 0.85 & 1181 & 4.1 & 46 & 15663 & 980 & 90.5 & 142.06 \\
\hline 8 & Łódź & 359.00 & 5 & 10850 & 0.44 & -312 & 11.3 & 34 & 2562 & 655 & 20.6 & 93.50 \\
\hline 9 & Wrocław & 621.00 & 46 & 14915 & 1.02 & -19 & 5.2 & 41 & 8053 & 479 & 75.5 & 119.98 \\
\hline 10 & Lublin & 26.00 & 44 & 10886 & 0.32 & -58 & 9.6 & 35 & 2267 & 207 & 23.0 & 131.93 \\
\hline 11 & Kraków & 221.00 & 36 & 13056 & 0.20 & 123 & 5.4 & 42 & 8620 & 494 & 82.5 & 153.64 \\
\hline 12 & Rzeszów & 226.00 & 12 & 11525 & 0.46 & -16 & 7.8 & 33 & 1486 & 669 & 13.0 & 127.35 \\
\hline 13 & Zielona Góra & 613.00 & 57 & 11627 & 1.13 & -670 & 8.5 & 39 & 1144 & 133 & 18.0 & 95.04 \\
\hline 14 & Kielce & 262.00 & 11 & 13553 & 0.54 & -414 & 10.3 & 33 & 1378 & 226 & 12.0 & 116.17 \\
\hline 15 & Katowice & 694 & 21 & 12804 & 0.55 & 1309 & 4.9 & 34 & 1351 & 130 & 28 & 113.58 \\
\hline 16 & Opole & 174 & 33 & 12752 & 0.22 & -172 & 6.8 & 35 & 270 & 76 & 21 & 114.94 \\
\hline
\end{tabular}

\begin{tabular}{ccccccccccccc}
\hline No. & $\mathbf{1 2 a}$ & $\mathbf{1 3 a}$ & $\mathbf{1 4 a}$ & $\mathbf{1 5 a}$ & $\mathbf{1 6 a}$ & $\mathbf{1 7 b}$ & $\mathbf{1 8 b}$ & $\mathbf{1 9 b}$ & $\mathbf{2 0 b}$ & $\mathbf{2 1 b}$ & $\mathbf{2 2 b}$ & $\mathbf{2 3 b}$ \\
\hline $\mathbf{1}$ & 22863 & 52 & 169 & 299.00 & 10 & 0.67 & 14.0 & 0.86 & -1.68 & 101.50 & 3.0 & 186 \\
\hline $\mathbf{2}$ & 4926 & 19 & 131 & 375.00 & 5 & 0.85 & 3.0 & 0.80 & -5.80 & 94.22 & 4.0 & 174 \\
\hline $\mathbf{3}$ & 15918 & 45 & 151 & 739.00 & 4 & 0.85 & 6.0 & 0.87 & -3.07 & 116.44 & 4.0 & 200 \\
\hline $\mathbf{4}$ & 22786 & 25 & 158 & 1017.00 & 2 & 0.92 & 4.0 & 0.82 & -7.50 & 71.61 & 5.0 & 323 \\
\hline $\mathbf{5}$ & 5879 & 10 & 139 & 273.00 & 6 & 0.84 & 9.0 & 0.71 & -3.60 & 111.61 & 6.0 & 80 \\
\hline $\mathbf{6}$ & 18072 & 45 & 143 & 1396.00 & 5 & 0.66 & 11.0 & 0.74 & -0.06 & 102.50 & 5.0 & 861 \\
\hline $\mathbf{7}$ & 155703 & 266 & 116 & -634.00 & 5 & 0.52 & 11.0 & 0.69 & -5.25 & 118.60 & 5.0 & 2494 \\
\hline $\mathbf{8}$ & 15186 & 52 & 142 & 936.00 & 2 & 0.92 & 3.0 & 0.84 & -6.30 & 84.20 & 8.0 & 191 \\
\hline $\mathbf{9}$ & 47823 & 100 & 107 & 13.00 & 6 & 0.67 & 8.0 & 0.66 & -3.57 & 105.48 & 5.0 & 160 \\
\hline $\mathbf{1 0}$ & 8043 & 20 & 152 & 87.00 & 4 & 0.75 & 3.0 & 0.73 & -1.30 & 126.40 & 7.0 & 55 \\
\hline $\mathbf{1 1}$ & 62393 & 154 & 125 & 148.00 & 6 & 0.57 & 4.0 & 0.59 & -1.16 & 145.64 & 3.0 & 1181 \\
\hline $\mathbf{1 2}$ & 2301 & 110 & 137 & -187.00 & 9 & 0.81 & 10.0 & 0.80 & -1.56 & 121.96 & 6.0 & 64 \\
\hline $\mathbf{1 3}$ & 2151 & 10 & 129 & 686.00 & 5 & 1.06 & 9.0 & 0.87 & 0.13 & 90.04 & 5.0 & 82 \\
\hline $\mathbf{1 4}$ & $\mathbf{2 5 0 2}$ & 43 & 132 & 445.00 & 4 & 0.80 & 4.0 & 0.71 & -2.10 & 109.77 & 6.0 & 41 \\
\hline $\mathbf{1 5}$ & 6815 & 30 & 182 & 1361.00 & 2 & 0.87 & 11.0 & 1.18 & -10.50 & 100.46 & 6 & 110 \\
\hline $\mathbf{1 6}$ & 2633 & 11 & 165 & 899.00 & 3 & 0.89 & 6.0 & 0.85 & -4.32 & 105.56 & 3 & 156 \\
\hline & & & & & & & & & & $\mathbf{3 2}$ \\
\hline $\mathbf{N o}$ & $\mathbf{2 4 b}$ & $\mathbf{2 5 b}$ & $\mathbf{2 6 a}$ & $\mathbf{2 7 a}$ & $\mathbf{2 8 a}$ & $\mathbf{2 9 b}$ & $\mathbf{3 0 b}$ & $\mathbf{3 1 b}$ & $\mathbf{3 2 b}$ & $\mathbf{3 3 b}$ & $\mathbf{3 4 b}$ & $\mathbf{3 5 b}$ \\
\hline & & & & & & & & &
\end{tabular}


VERSITA

\begin{tabular}{|c|c|c|c|c|c|c|c|c|c|c|c|c|}
\hline No. & $24 b$ & $25 b$ & $26 a$ & $27 a$ & $28 a$ & $29 b$ & $30 \mathrm{~b}$ & $31 \mathrm{~b}$ & $32 b$ & $33 b$ & $34 \mathrm{~b}$ & $35 b$ \\
\hline 1 & 80 & 4099 & 11190 & 24.6 & 2.4 & 1744 & 2253 & 1028 & -83 & 91 & 144003 & 382 \\
\hline 2 & 60 & 3000 & 3409 & 23.9 & 2.5 & 1988 & 905 & 442 & -277 & 309 & 55871 & 344 \\
\hline 3 & 66 & 1688 & 10095 & 24.8 & 2.5 & 1350 & 1951 & 989 & 32 & -681 & 127018 & 343 \\
\hline 4 & 55 & 1000 & 7593 & 22.9 & 2.6 & 2024 & 1876 & 955 & -1115 & -308 & 109823 & 376 \\
\hline 5 & 28 & 2000 & 5698 & 24.3 & 2.4 & 2890 & 1435 & 692 & -414 & 557 & 94169 & 364 \\
\hline 6 & 55 & 402 & 14122 & 27.9 & 2.3 & 2106 & 2907 & 1178 & -2493 & 443 & 178051 & 382 \\
\hline 7 & 71 & 4751 & 46458 & 28.3 & 2.1 & 3326 & 8217 & 3566 & 7102 & 1277 & 549744 & 353 \\
\hline 8 & 57 & 634 & 22823 & 25.0 & 2.2 & 2514 & 3233 & 1333 & -1467 & -4111 & 212071 & 333 \\
\hline 9 & 55 & 2851 & 16216 & 26.0 & 2.3 & 2162 & 3156 & 1331 & 615 & -71 & 203364 & 360 \\
\hline 10 & 63 & 830 & 8913 & 24.0 & 2.5 & 2363 & 1736 & 648 & -1124 & 208 & 108126 & 297 \\
\hline 11 & 48 & 1380 & 17460 & 24.9 & 2.3 & 2314 & 3732 & 1852 & 975 & 422 & 243499 & 376 \\
\hline 12 & 73 & 2299 & 3406 & 24.2 & 2.7 & 1532 & 1013 & 328 & 275 & 557 & 56830 & 344 \\
\hline 13 & 60 & 1603 & 2653 & 25.4 & 2.4 & 2017 & 593 & 285 & 140 & 107 & 37680 & 303 \\
\hline 14 & 52 & 817 & 4335 & 23.2 & 2.5 & 1859 & 1037 & 313 & -699 & 64 & 61305 & 306 \\
\hline 15 & 110 & 1500 & 8389 & 25.9 & 2.3 & 1880 & 615 & 651 & -1160 & -957 & 90343 & 394 \\
\hline 16 & 60 & 1170 & 2699 & 25.2 & 2.5 & 1273 & 225 & 260 & -169 & -48 & 38435 & 348 \\
\hline
\end{tabular}

*-identified in accordance with the "rating toolkit".

Source: data supplied by the Central Statistical Office, National Bank of Poland, SARFIN and AMRON databases, Rzeczpospolita daily's ranking of local governments. 